\title{
An overview of oak silviculture in the United States: the past, present, and future
}

\author{
R Rogers 1, PS Johnson 2, DL Loftis 3
}

\author{
1 University of Wisconsin, Stevens Point, WI 54481; \\ 2 USDA Forest Service, North Central Forest Experiment Station, 65211 Columbia, MO; \\ 3 USDA Forest Service, Southeastern Forest Experiment Station, Asheville, NC, 28802 USA
}

(Received 6 January 1993; accepted 2 June 1993)

\begin{abstract}
Summary - Oaks (Quercus) are important components of forest systems throughout the United States. This overview describes past, present, and future silvicultural practices within the oakhickory ecosystem of the United States. Past land-use activities favored oak development, but wildfire and livestock grazing controls have caused severe oak regeneration problems that were not recognized until recently.Prescriptions for weedings, cleanings and the use of stocking charts to control intermediate thinnings were early silvicultural developments. More recently, growth and yield models for managed stands were developed to predict current and future timber volumes. Currently, silviculturists are developing solutions to natural and artificial regeneration problems. Research results indicate that, other factors being equal, regeneration success is favored by simultaneously reducing over and understory densities and that oak seedling survival and development is enhanced in large seedlings that have high root to shoot ratios. Future silvicultural practices will have an ecosystems focus.
\end{abstract}

oak / silviculture / regeneration / thinning / model

Résumé - Un aperçu global de la sylviculture des chênes aux États-Unis : passé, présent, futur. Aux États-Unis, les chênes (Quercus) constituent partout des composants importants des systèmes forestiers. Ce travail a pour but de décrire les pratiques anciennes, actuelles et futures à l'intérieur de l'écosystème chêne-hickory des États-Unis. Autrefois, les activités réalisées dans I'utilisation des terres favorisaient le développement des chênes. Toutefois, la lutte contre les incendies de forêt spontanés et le pâturage du bétail a entrainé des problèmes sévères pour la régénération des chênes, problèmes non reconnus juqu'à ces derniers temps. Les prescriptions pour le désherbage, le défrichement et l'emploi des tableaux de stockage pour contrôler l'éclaircissement intermédiaire de sylviculture étaient des anciens développements en sylviculture. Plus récemment, on a développé des modèles de croissance et de rendement pour les peuplements aménagés afin de prévoir les volumes de bois actuels et futurs. Actuellement, les sylviculteurs sont en train de formuler des solutions aux problèmes de régénération naturelle et artificielle. Les résultats des chercheurs indiquent, que, toutes choses égales d'ailleurs, le succès en régénération est favorisé par la réduction spontanée de la densité des voûtes inférieure et supérieure et que la survie et le développement des plants de chêne sont augmentés chez les grands semis qui ont un rapport racine-pousse élevé. $\dot{A}$ l'avenir, les pratiques de sylviculture seront centrées sur les écosystèmes. 


\section{INTRODUCTION}

The International Union of Forestry Research Organizations (IUFRO) held its 100 th anniversary meeting during the period 31 August to 4 September, 1992 at the IUFRO birthplace in Eberswalde, Germany. The theme of this meeting revolved around where we have been, where we are, and where we are going in forestry research. The paper presented here is based on a talk delivered at this special meeting.

Time and space limitations necessarily forced us to define more narrowly the scope of the topic of oak silviculture in the United States. Hence, the material here should not be viewed as a comprehensive treatment of the subject, but rather as a document that highlights certain events that we believe are important.

\section{DISCUSSION}

Forestry in the United States had its beginnings about the time that IUFRO was founded in 1892. Although the American Forestry Association was founded in 1875 in order to educate people about the need for forest conservation measures, the conservation movement in the United States became a reality when our national forest system was started in 1891, just a year before IUFRO came into being. However, scientific forestry in the United States was not introduced until after the turn of the century when the US Forest Service was established in 1905 and IUFRO was already $13 \mathrm{yr}$ old. We owe our forestry origins to Europe because it was European methodology that was transplanted to the US by early American foresters like Gifford Pinchot, the first chief forester of the US Forest Service.
Early forestry programs in the United States focused primarily on protectionist activities such as wildfire prevention and suppression. These activities extended to all tree species and ecosystems including those containing oaks (Quercus).

Oaks have been and currently are extremely important components of forest systems throughout the United States. They extend from the northeastern hardwood forests bordering the Atlantic Ocean to the western hardwood rangelands of California, Oregon, and Washington and from the northern mixed conifer forests of the Great Lakes and Canada southward to the bottomland hardwood and southern yellow pine woodlands that adjoin the Gulf of Mexico.

Although oaks are widespread, they predominate in central and eastern United States forest and form the upland and bottomland oak ecosystems. Together, these ecosystems encompass $\approx 114$ million acres and provide a habitat for $>75$ tree species, 230 species of birds and mammals, plus numerous other plants and animals. This covers an area which is $\approx 30 \%$ larger than all of Germany.

Generalizing about oak silviculture over time and space is difficult because there are many oaks that grow under a wide range of conditions. Nevertheless, by focusing attention on the upland regions of eastern oak ecosystems, we can make several universal statements about early silvicultural practices and how those practices have evolved to address current silvicultural problems, and how they may be modified and used in the future.

Usually forest resource managers adopt or modify silvicultural practices after considering both natural and social forces that act upon the forest. Our current oak forest were shaped by presettlement and early settlement activities. These activities favored oak development by disrupting sec- 
ondary succession. Fires during presettlement, and land clearing combined with frequent fires and grazing by cattle during settlement times gradually eliminated competing species or deterred their development (Lorimer, 1989; Abrams, 1992).

Oaks became more important just prior to and during the 1930 s as a consequence of the demise of the American chestnut (Castenea dentata) due to chestnut blight (Endothia parasitica). During this time, $85 \%$ of the eastern upland oak forest contained oak. These forests were mostly second-growth stands of sprout origin. Despite the high percentage of oak in these stands, most were understocked, unhealthy, and in a run-down condition as a result of indiscriminate cutting, grazing, fire, disease, and insects (Schnur, 1937).

Understandably, early silvicultural practices were geared toward modifying stand density and protecting oak stands from destructive agents such as wildfires and grazing. Paradoxically, early protectionist silvicultural practices unwittingly created a regeneration problem that was not recognized until much later. These past land-use activities and accompanying silvicultural prescriptions resulted in ecologically unstable even-aged stands dominated by oak.

Early foresters like Luther Schnur (1937) conducted studies to develop yield, stand, and volume tables for these evenaged upland oak forests. He found that fully stocked oak stands of average site quality $(18 \mathrm{~m}$ tall at $50 \mathrm{yr}$ ) grow at an annual rate of $3.36 \mathrm{~m}^{3}$ per ha if they are not thinned.

During the 1930s, silvicultural activites were geared mainly toward providing adequate growing space for featured species, such as oaks, and to ensuring their perpetuation in future stands. Notable treatments included weedings and cleanings, and intermediate thinnings. Stands were regenerated by conventional clearcutting, seedtree and shelterwood methods.
Silviculturists at that time realized that merchantable yield could be influenced by manipulating stand density. However, they needed to determine which density levels produced the greatest yield and further how stand density levels affected tree quality. Because of the need for this kind of information, the US Forest Service initiated studies in the late 1940 s to determine the extent to which density effected growth and yield of oak in the upland oak region.

In this regard, tree stand density is typically expressed by units such as basal area per unit area or numbers of trees per unit area. While these units provide objective measures of stand density silviculturists soon realized they were poor measures or indicators of the extent to which trees within the stand were using space available to them.

Lexan (1939) and Chisman and Schumacher (1940) worked on this problem and developed a method called tree area ratio for relating a tree's growing space requirement to its stem diameter. But it remained for Samuel Gingrich (1967) to adapt the findings of these researchers by integrating density measures and stand size descriptors with tree area ratio. Gingrich used the previously mentioned oak growth and yield studies initiated in the 1940 s by the US Forest Service to determine the growing space requirements of the upland oaks. One of the most useful results of Gingrich's work was the development of a stocking chart (fig 1).

Gingrich's stocking chart for upland oaks is a graph that relates the amount of growing space in a given stand to a reference stand that is at average maximum density or $100 \%$ stocked. The vertical axis shows basal area per acre and the horizontal axis shows the number of trees per acre. Quadratic mean stand diameter, a measure of stand size, and stocking ex- 


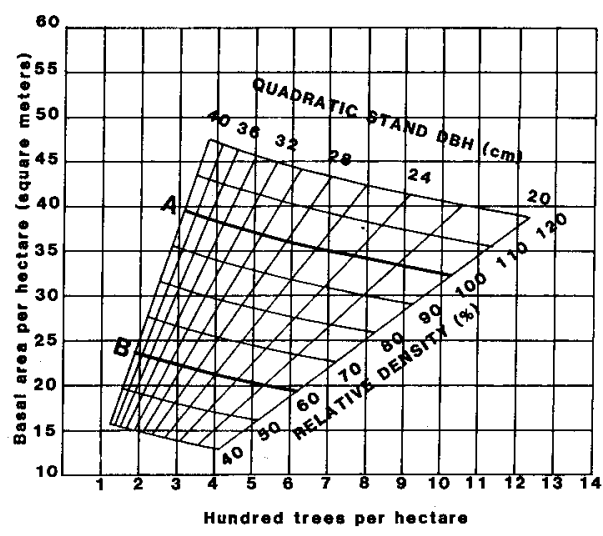

Fig 1. The relation of basal area, number of trees, and quadratic stand (average) diameter to relative density (stocking \%) for forests of average uniformity. The area between curves $A$ and $B$ indicates the range of stocking where trees can fully utilize the growing space. A separate chart must be constructed for each species or species group.

pressed as percent relative density are overlayed on the graph. This chart depicts the relation between stocking and density and allowed us, for the first time, to compare the adequacy of site utilization in stands of different ages and site qualities. This is possible because a constant stocking percent allocated tree area on the basis of tree size. Stocking charts are routinely used to evaluate stand denstity in oak stands to determine the need for thinning.

In addition to developing the stocking chart, Gingrich also discovered that the greatest volume returns resulted from thinning stands regularly at $10-$ to $15-\mathrm{yr}$ intervals beginning at age $10 \mathrm{yr}$. He found that such a stand would at least double the merchantable volume produced by a similar but unthinned stand over the course of a rotation on the same site (Gingrich, 1971).

This study and others provided the basis for constructing computer models during and following the 1970's that simulated growth and yield in upland oak stands with and without cultural treatment. Some examples are GROAK, SILVA, TIMPIS, COPPICE, G-HAT, OAKSIM and TWIGS (Dale, 1972; Rogers and Johnson, 1984; Hilt, 1985; Marquis, 1986; Perkey, 1986; Shifley, 1987).

With some exceptions, most oak cultural work has focused on intermediate treatments which alter stand density and composition by thinning. Less attention was given to the regeneration phase of oak management. Traditional regeneration techniques were relied upon to regenerate oak stands following stand removal. However, it was not until the 1970's that foresters began to realize the seriousness of the regeneration failures that were occurring thoughout the oak region.

The scope of the problem was not appreciated until methods were available to evaluate the adequacy of oak advance reproduction (Sander et al, 1984).

Subsequently, silviculturists learned that for many oak ecosystems, regeneration success was related to the size and numbers of advance regeneration (Sander, 1971; Sander et al, 1984). Past and current regeneration surveys showed a lack of adequate size and numbers of oak regeneration with the result that some oak forests were being displaced by more tolerant species (Nowacki et al, 1990). The cumulative effect of this and other factors like the spread of oak wilt, gypsy moth, and urban development has resulted in a substantial decline in the areal importance of oak.

Substantial research is currently underway to better understand natural regeneration processes in oak ecosystems. Such 
research is called regeneration ecology. However, generalizing about the problem of oak regeneration across species and ecosystems is difficult because of differences in regeneration strategy among the oaks. Seeding, various modes of sprouting, and vegetative multiplication represent different tactics that oaks employ in their regeneration strategy. Although all North American oaks rely to some extent on both seeding and sprouting, the extent to which they rely on one tactic over the other differs greatly among species.

Oak reproduction consists of seedlings, seedling sprouts, and stump sprouts. When present before a silvicultural event such as clearcutting or shelterwood removal, all 3 growth forms are collectively termed advance reproduction. All living oaks from seedlings to mature trees thus can contribute to the regeneration potential of a stand.

Oak regeneration in the droughtaffected oak forests of the Missouri Ozarks is largely dependent on sprouting, and with few exceptions these forests are seldom successionally displaced by other species (Sander et al, 1984).

Oaks of the arid Southwest may regenerate almost exclusively by sprouting from below-ground root-like structures: lignotubers, rhizomes, and true roots (Tiedemann et al, 1987).

Northern red oak, a mesic species, is flexible in its regeneration strategy because it can regenerate from seedlings established after a harvest as well as from sprouts from large parent trees of advanced age. However, unlike the xeric oak forests of the Missouri Ozarks and elsewhere, northern red oak forests are frequently displaced successionally by other species (Johnson, 1976; Lorimer, 1983; Crow, 1988; Loftis, 1990a; Nowacki et al, 1990).

Seedlings combined with sprouting is an important regeneration tactic of some bottomland oak species like water oak and
Nuttall oak. However, bottomland oak forests are often displaced by other species because of prolonged periods with little or no oak advance reproduction due to low seedling survival rates and infrequent acorn crops (Johnson, 1975; Johnson and Krinard, 1983; Aust et al, 1985).

We are learning more about the population dynamics of oak advance reproduction. Several recent studies provide evidence that the occurrence of new seedlings is predictable only probabilistically, while seedling survival is more predictable deterministically because it can be related to stand and site characteristics such as over and understory density, light, moisture, frost and predation by animals (Beck 1970; Loftis, 1988, 1990a; Crow, 1992).

Successional replacement of oaks by oaks is heavily dependent upon conditions that favor the long-term accumulation of oak reproduction with a high root to shoot ratio combined with a large root mass (Johnson, 1979; Dickson, 1991). Lacking those characteristics, oaks are usually at a competitive disadvantage. High root to shoot ratios are obtained in oaks by recurrent shoot dieback. The accumulation of oak reproduction under a parent stand is one of the most important aspects of the regeneration ecology of oaks.

Recurrent fire promotes the accumulation of oak reproduction. When fires are frequent and intense, oak savannas may result (Curtis, 1959; Haney and Apfelbaum, 1990). But not all oak-dominated ecosystems require fire or disturbance for their sustainment. Many dry oak forests like those in Missouri appear to be relatively stable communities and can accumulate oak reproduction for 50 or more yr (Sander, 1979). Such forests are called autoaccumulators.

Despite the complexity of the oak regeneration problem, most oak researchers 
agree that there is a general relation between site quality and regeneration success: the better the site, the more difficult it is to regenerate oaks (Arend and Scholz, 1969; Trimble, 1973; Lorimer, 1989, Loftis, 1990b).

Although there are no universal prescriptions for the regeneration problem, we have learned that modified shelterwood systems increase both seedling survival and dominance probabilities in some oak forests. Such systems use a series of partial cuts to reduce both canopy and subcanopy densities prior to overstory removal. Decreasing the density of both canopy layers allows more light to reach the forest floor thereby increasing both seedling survival and dominance probabilities of oak advance reproduction and/or underplanted oak seedlings (Beck, 1970; Loftis, 1988, 1990a; Crow, 1992).

We have presented a brief view of the past and current state of oak silviculture in the United States. But, what does the future hold for us? We will limit our speculations to the next decade. We believe great effort will be expended in continuing the research in oak regeneration ecology. Predictive regeneration models for oak ecosystems will be developed just as various oak growth and yield models have been developed over recent years. Such predictive models have been particularly useful tools for the silviculturist.

However, these new regeneration models will differ from growth and yield models whose usefulness depends upons the certainty of their predictions. Rather, the new regeneration models will capture the chaotic regeneration process by modelling the probability of regeneration events. For example, SIMSEED, developed by Rogers and Johnson (1993) is a probabilistic simulation model of advance reproduction density of northern red oak. Any given run of the model shows the pattern of the distri- bution of numbers of advance red oak reproduction under equilibrium conditions (fig 2). Seedling survival and seedling input rates are assumed to be intrinsic to a particular oak ecosystem. The value of the model is not that it will accurately predict the numbers of advance regeneration on the ground in a given year, but rather that it gives us good information about the likelihood of observing such a number in a given year. In certain respects, likelihoods provide a better basis for making forest management decisions than exact values.

Such models will be ecosystem specific and will be related to ecological classification systems currently being developed for many of our ecosystems. Forest managers will be able to evaluate alternative silvicultural prescriptions suggested by using these models to simulate stand dynamics in specific oak ecosystems. Oak silviculture of the future will rely on maintaining links between observable responses, computer simulation models, ecological classification systems, geographic information systems, and global positioning technology.

For the most part, past oak silviculture in the United States has focused on single species and single values. Future silviculture will deal with oaks as part of an eco-

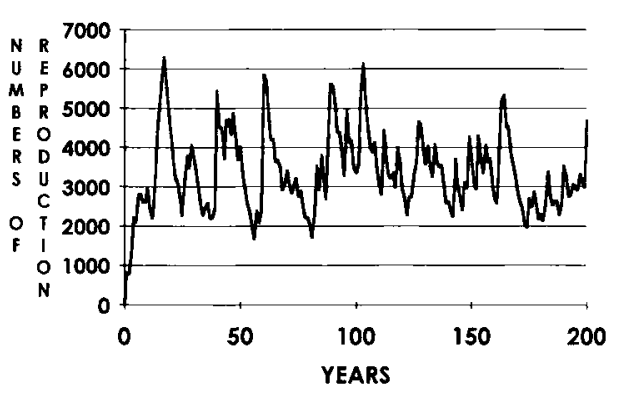

Fig 2. Simulated 200-yr fluctuation in northern red oak advance reproduction density based on the SIMSEED model (Rogers and Johnson, 1994). 
logical unit capable of having multiple values. Our improved understanding of ecophysiological processes together with the new emerging technologies mentioned previously will help us develop cultural systems for managing communities of oak forests to achieve general goals like biodiversity and old growth as well as for prepetuating specialized communities like oak savannas.

\section{ACKNOWLEGMENTS}

This paper was presented at the Centennial Meeting of the International Union of Forestry Organizations in Eberswalde/Berlin, Germany, in September 1992.

\section{REFERENCES}

Abrams MD (1992) Fire and the development of oak forests. Bio Sci 42, 346-353

Arend JL, Scholz HF (1969) Oak forests of the Lake States and their management. US For Ser Res Pap NC 31

Aust WM, Hodges JD, Johnson RL (1985) The origin, growth and development of natural, pure, even-aged stands of bottomland oak. In: 3rd Biennial Southern Silvic Res Conf Proceedings (E Shoulders, ed) US For Serv Gen Tech Rep SO 54, 163-170

Beck DE (1970) Effect of competition on survival and height growth of red oak seedlings. US For Serv Res Pap SE 56

Chisman HH, Schumacher FX (1940) On the tree-area ratio and certain of its applications. J For 38, 311-317

Crow TR (1988) Reproduction mode and mechanisms for self-replacement of northern red oak (Quercus rubra) - a review. For Sci 34, $19-40$

Crow TR (1992) Population dynamics and growth patterns for a cohort of northern red oak (Quercus rubra) seedlings. Oecol Plant $91,192-200$

Curtis JT (1959) The Vegetation of Wisconsin. Univ Wisconsin Press, Madison, WI
Dale ME (1972) Growth and yield predictions for upland oak stands 10 years after initial thinning. US For Serv Res Pap NE 241

Dickson RE (1991) Episodic growth and carbon physiology in northern red oak. In: Proc Oak Res Upper Midwest (SB Laursen, JF Deboe, eds) Minn Ext Sen Publi NR-BU 5663-S, 117-124

Gingrich SF (1967) Measuring and evaluating stocking and stand density in upland hardwood forest in the central states. For Sci 13, 38-52

Gingrich SF (1971) Management of young and intermediate stands of upland hardwoods. US For Sen Res Pap NE 195

Haney A, Apfelbaum SI (1990) Structure and dynamics of midwest oak savanna. In: Proc Manage Dyn Ecosystems (JM Sweeney ed) N Central Sect Wildl Soc, 19-30

Hilt DE (1985) OAKSIM: an individual-tree growth and yield simulator for managed, even-aged, upland oak stands. US For Serv Res Pap NE 562

Johnson PS (1975) Growth and structural development of red oak sprout clumps. For Sci 21, 413-418

Johnson PS (1976) Modal development of regeneration in clearcut red oak stands in the Driftless Area. In: Central Hardwood For Conf/Proc (JS Fralish, GT Weaver, RC Schlesinger, eds) S ILI Univ, 455-475

Johnson PS (1979) Shoot elongation of black oak and white oak sprouts. Can J For Res 9 , 489-494

Johnson PS, Rogers R (1984) Predicting 25thyear diameters of thinned stump sprouts of northern red oak. J For 82, 616-619

Johnson RL, Krinard RM (1983) Regeneration in small and large sawtimber sweetgum-red oak stands following selection and seed tree harvest: 23-year results. Sout J Appl For 7, 176184

Lexen B (1939) Space requirements of ponderosa pine by tree diameter. US For Serv Res Note PSW 63

Loftis DL (1988) Regenerating oaks on highquality sites, and update. In: Proc Guidelines Regen Appalachain Hardwood Stands ( $\mathrm{HC}$ Smith, AW Arlyn, WE Kidd Jr, eds) Soc Am For Publi 88-03, 199-209 
Loftis DL (1990a) Predicting post-harvest performance of advance red oak reproduction in the southern Appalachians. For Sci 36, 908-916

Loftis DL (1990b) A shelterwood method for regenerating red oak in the southern Appalachians. For Sci 36, 917-929

Lorimer CG (1983) Eighty-year development of northern red oak after partial cutting in a mixed-species Wisconsin forest. For Sci 29 , 371-383

Lorimer CG (1989) The oak regeneration problem: new evidence on causes and possible solutions. Univ Wisconsin For Res Anal. Madison, WI, No 8

Marquis DA (1986) SILVAH: a stand analysis, prescription and management simulator program for hardwood stands in the Alleghenies. In: For Microcomp Software Symp 1986, June 29-July 2, Morgantown, WV (HV Wiant, DO Yandel, WE Kidd, eds) W Virginia Univ, 224-240

Nowacki GH, Abrams MD, Lorimer CG (1990) Composition, structure and historical development of northern red oak stands along an edaphic gradient in north-central Wisconsin. For Sci 36, 276-292

Perkey A (1986) Stand projection using GROAK and GROPOP. In: For Microcomp Software Symp 1986, June 29-July 2, Morgantown,
WV (HV Wiant, DO Yandel, WE Kidd, eds) W Virginia Univ, 67-69

Rogers R, Johnson PS (1994) SIMSEED: a simulator of northern red oak advance reproduction density. US For Serv Res Pap NC (in press)

Sander IL (1971) Height growth a new oak sprouts depends on size of advance reproduction. J For 69, 809-811

Sander IL (1979) Regenerating oaks. In: Proc Nat Silvic Workshop. US For Sen 212-221

Sander IL, Johnson PS, Rogers R (1984) Evaluating oak advance reproduction in the Missour Ozarks. US For Serv Res Pap NC 251

Schnur GL (1937) Yield, stand, and volume tables for even-aged upland oak forests. US For Serv Tech Bull 560

Shifley SR (1987) A generalized system of models forecasting Central States tree growth. US For Serv Res Pap NC 279

Tiedemann AR, Clary WP, Barbour RJ (1987) Underground systems of Gambel oak (Quercus gambelii) in central Utah. Am J Bot 74, 1065-1071

Trimble GR (1973) The regeneration of Central Appalachian hardwoods with emphasis on the effects of site quality and harvesting practice. US For Sen Res Pap NE 282 